\title{
Diversity of Pyrite-Hosted Solid Inclusions and Their Metallogenic Implications-A Case Study from the Myszków Mo-Cu-W Porphyry Deposit (the Kraków-Lubliniec Fault Zone, Poland)
}

\author{
Beata Naglik ${ }^{1, *}$, Magdalena Dumańska-Słowik ${ }^{2} \mathbb{D}$, Tomasz Toboła ${ }^{2} \mathbb{D}$, Paweł Derkowski ${ }^{3}$, Ryszard Habryn $^{1}$ \\ and Marek Markowiak ${ }^{1}$
}

\section{check for updates \\ Citation: Naglik, B.; \\ Dumańska-Słowik, M.; Toboła, T.; Derkowski, P.; Habryn, R.; Markowiak, M. Diversity of Pyrite-Hosted Solid Inclusions and Their Metallogenic Implications-A Case Study from the Myszków Mo-Cu-W Porphyry Deposit (the Kraków-Lubliniec Fault Zone, Poland). Minerals 2021, 11, 1426. https://doi.org/10.3390/ $\min 11121426$}

Academic Editor: Liqiang Yang

Received: 17 November 2021 Accepted: 12 December 2021 Published: 16 December 2021

Publisher's Note: MDPI stays neutral with regard to jurisdictional claims in published maps and institutional affiliations.

Copyright: (c) 2021 by the authors. Licensee MDPI, Basel, Switzerland. This article is an open access article distributed under the terms and conditions of the Creative Commons Attribution (CC BY) license (https:// creativecommons.org/licenses/by/ $4.0 /)$.
1 Polish Geological Institute-National Research Institute, Upper Silesian Branch, 41-200 Sosnowiec, Poland; rhab@pgi.gov.pl (R.H.); marek.markowiak@pgi.gov.pl (M.M.)

2 Faculty of Geology, Geophysics, and Environmental Protection, AGH University of Science and Technology, 30-059 Kraków, Poland; dumanska@agh.edu.pl (M.D.-S.); tobolatomasz@agh.edu.pl (T.T.)

3 Polish Geological Institute-National Research Institute, 00-975 Warsaw, Poland; pder@pgi.gov.pl

* Correspondence: bnag@pgi.gov.pl

\begin{abstract}
Pyrite from the central part of the Myszków porphyry deposit in Poland was investigated using a combination of reflected and transmitted polarizing microscopy, back-scattered imaging with energy-dispersive X-ray spectroscopy, and Raman micro-spectroscopy. Five generations of pyrite (I-V) found in hydrothermal veins were distinguished, differing in morphology, microtexture, and the types and amounts of solid inclusions. In general, pyrite hosts a diversity of mineral inclusions, including both gangue and ore phases, i.e., chlorite, quartz, monazite, cerianite-(Ce), xenotime, K-feldspars, albite, sericite, barite, magnetite, chalcopyrite, galena, sphalerite, bastnaesite (Ce), bismuthinite, native silver, cassiterite, rutile, anatase, and aikinite-group species. The presence of inclusions is good evidence of various stages of the evolution of the hydrothermal lode system ranging from high- to low-temperature conditions. During the formation of stockworks, some fluctuations in the physicochemical conditions of mineralizing fluids were indicated by the occurrence of cassiterite formed from acidic, reducing solutions, and hematite hosted in xenotime or REE phases found in pyrite, which signal more oxidizing conditions. Periodically, some episodes of boiling in the hydrothermal, porphyry-related system were recorded. They were mainly evidenced by the presence of (1) lattice-bladed calcite found in the close vicinity of pyrite II, (2) irregular grain edges of pyrite I, (3) clustered micropores in pyrite I, and (4) the variety of mineral inclusions hosted in I and II generations of pyrite.
\end{abstract}

Keywords: pyrite; porphyry ore deposit; inclusion; microtexture; boiling

\section{Introduction}

Pyrite is the most abundant sulfide mineral in the Earth's crust and a major component of many types of hydrothermal ore systems, including porphyry copper deposits [1], sediment- and volcanic-hosted massive sulfide deposits [2,3], Mississippi Valley-type $\mathrm{Pb}-$ $\mathrm{Zn}$ deposits [4], lode Au deposits [5,6] and epithermal Au-Ag deposits [7]. It can be formed by the replacement of a primary pyrrhotite [8], as has been confirmed by natural findings [9]. As it is associated with minerals formed before, during, and after the ore deposition, pyrite provides a unique view into the evolution of fluids and the physicochemical conditions of hydrothermal lode systems over a wide range of mineralization stages [10-13].

The chemical composition of pyrite originating from hydrothermal environments deviates significantly from the ideal formula of $\mathrm{FeS}_{2}$, and presents a wide range of elements that may be incorporated within its structure, especially in low-temperature conditions [14]. The most common are substitutions of $\mathrm{Au}, \mathrm{Ag}, \mathrm{Cu}, \mathrm{Zn}, \mathrm{Co}, \mathrm{Ni}, \mathrm{As}, \mathrm{Sb}, \mathrm{Se}, \mathrm{Te}$, and Hg [1,14], 
some of which could be hosted in economically valuable amounts. A wide variety of trace elements might be present in pyrite as nano-sized inclusions or non-stoichiometric substitutions. Hence, the chemical composition of pyrite has attracted attention as a potential tracer of ore-forming processes, including information on the transport and depositional mechanisms of precious and critical elements in hydrothermal systems [1,15].

In the last few years, pyrite has also been considered as a candidate for near-infrared (NIR) microthermometry of fluid inclusions. The first report of microthermometric data of pyrite crystals from the Lepanto high-sulfidation $\mathrm{Cu}-\mathrm{Au}$ deposit in the Philippines was published by Mancano and Campbell [16]. Since then, it has been shown that the transparency of pyrite to NIR radiation varies from deposit to deposit according to its variable chemical composition and textural features [10,16-18].

Pyrite is also a host for abundant solid inclusions, represented mostly by sulfides, sulfosalts, and native metals containing significant amounts of $\mathrm{Pb}, \mathrm{Hg}, \mathrm{Bi}, \mathrm{Sb}, \mathrm{Au}, \mathrm{Ag}, \mathrm{Ni}$, $\mathrm{Te}$, and As [14]. These mineral inclusions have been mainly found in low-temperature, high-defect pyrite, and can constitute the source of most trace elements in pyrite [14]. Hence, the interpretation of sulfide mineral textures and the distribution of inclusions is critical for assessing trace-element content and sulfur isotopes [11,12,19-21], especially to avoid over- or under-estimation of the elemental concentrations. In some cases, pyritehosted mineral inclusions themselves provide a view into fluid evolution processes, heavy metal dissolution, and transportation mechanisms as well as precipitation pathways of ore minerals.

The aim of this paper was to identify solid-inclusion assemblages hosted in various generations of pyrite from the Myszków porphyry Mo-Cu-W deposit in the KrakówLubliniec Fault Zone (KLFZ), Central Poland, genetically linked to the Variscan granitoid intrusion and porphyry dykes. As previously discovered, pyrite from the marginal zone of the Mo- $\mathrm{Cu}-\mathrm{W}$ ore body bears many micro-sized inserts of rare phases, including some tellurium and bismuth minerals as well as sulfosalts of various compositions, i.e., $\mathrm{Pb}$, $\mathrm{Ag}, \mathrm{Cu}$, and $\mathrm{Bi}$, up to the most common mineral inclusions such as chalcopyrite [22]. In this paper, pyrite from the central part of the deposit was analyzed in terms of its solid inclusions, with respect to the particular mineralization stages. The included mineral phases were evaluated by means of their utility for assessing petrogenetic information on ore-forming processes and the crystallization environment of the host crystals. Moreover, microtextural observations of pyrite and associated gangue minerals were integrated to provide insight into some physicochemical processes, e.g., the boiling and non-boiling events that took place during the evolution of the hydrothermal lode system.

\section{Geological Settings}

Magmatic-related mineralization of the Myszków Mo-Cu-W deposit and other prospects along the KLFZ occur at the contact zone between two distinctive tectonic units: (1) the Upper Silesian Block and (2) the Małopolska Block (Figure 1), both of which have their own history of evolution and paleotectonic development $[23,24]$. The Upper Silesian Block (USB) constitutes a sector of composite Brunovistulicum Terrane (BVT), which originated from the accretion of Gondwana-derived microplates during the Cadomian Orogeny [25,26]. In contrast, the Małopolska Block (MB) - a tectonic unit of unknown age of consolidationdisplays linkages to both the Baltica and peri-Gondwana paleocontinents [26-29]. Hence, the KLFZ is a part of the Trans-European Suture Zone, one of the most important composite suture zones in Europe [30-35].

The Myszków Mo-Cu-W deposit provides an unusual example of porphyry-style mineralization with no analogues in Europe. It differs from the other European Cu-Motype porphyry systems due to its anomalously high tungsten content and the presence of various W-bearing minerals in the ore-related pluton [36]. As is well known, there was no suitable environment for the development of classic porphyry-type mineralization along the Kraków-Lubliniec igneous belt [37]. Hence, the geotectonic model for the origin of this deposit is still a matter of debate. According to the latest interpretation [37], the genesis of 
the Myszków Mo-Cu-W deposit and other prospects along the KLFZ could be correlated with the regional tectonic movements (strike-slip activity) and magma emplacements produced by decompression melting. A continent-continent Variscan collision between Bohemian Massif and Brunovistulicum caused a reactivation of the MB and USB margins, leading to widespread magmatism and associated hydrothermal events along the KrakówLubliniec belt.

The ore mineralization at the KLFZ is closely related to the post-intrusive tectonics, the earliest stages of which were associated with the cooling of the granitoid body [36]. Precipitation of ore minerals resulted from both the contact metamorphism (early stage: skarn-type mineralization) and post-magmatic activity (main and late stage: hydrothermal mineralization). The ore mineralization at the KLFZ occurred in a series of pulses controlled by different fissure systems, which are marked by diverse paragenetic sequences [36,38-40]. Most of the principal ore minerals (pyrite, chalcopyrite, and molybdenite) were deposited during several different stages of mineralization while the others (e.g., sphalerite, scheelite, hematite, and tetrahedrite) occurred in specific assemblages.

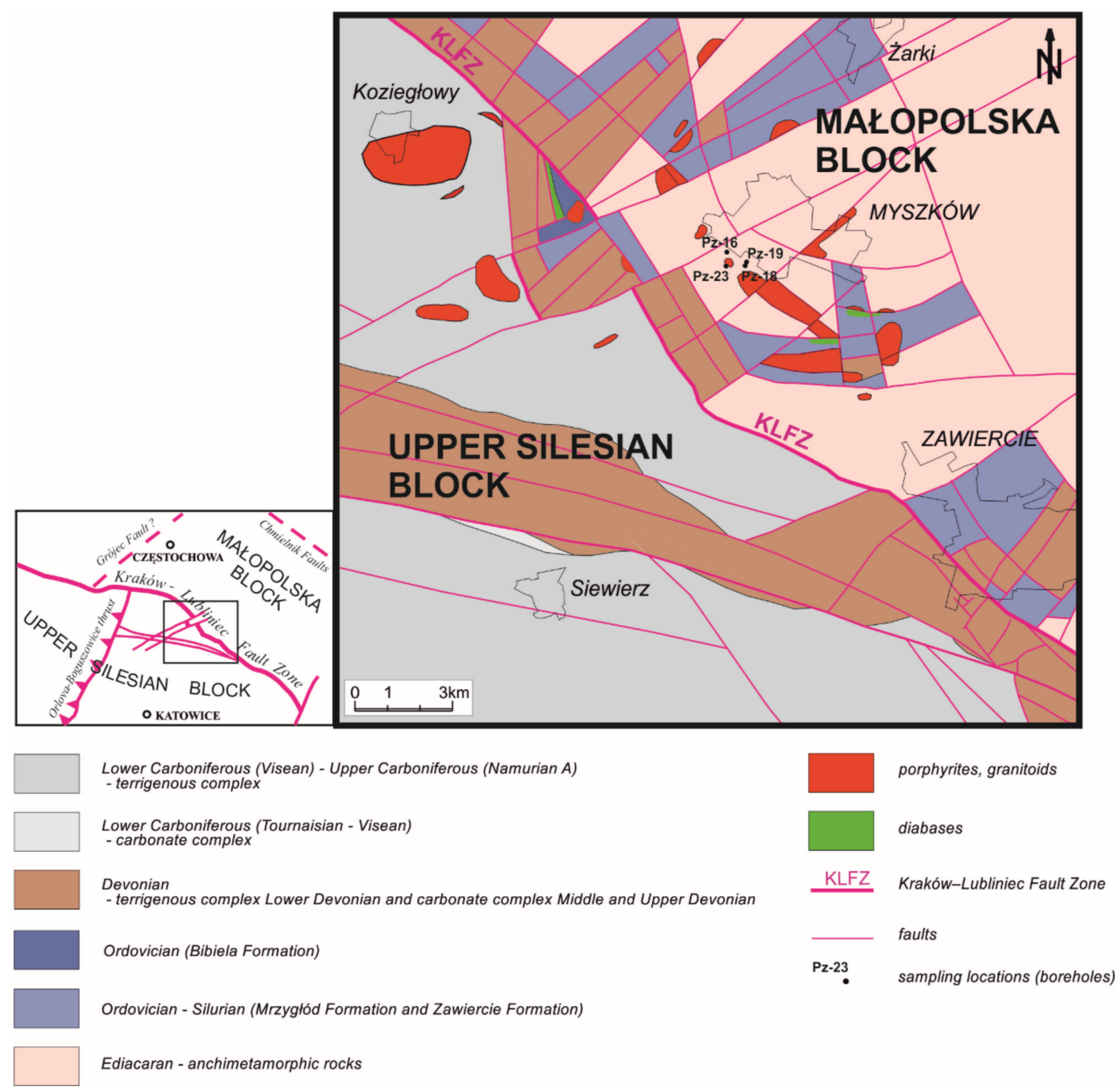

Figure 1. Geological map of studied area (modified after Buła et al. (2008)) [41]. 
Generally, three periods of mineralization are defined at the Myszków deposit: (1) the early, skarn-forming period (period I), (2) the main, hydrothermal period (period II), and (3) the late, post-ore period (period III) [36,38]. Period I is represented by magnetite-sulfide mineralization that is present in hornfelses, skarns, and metasomatites. Within period II, different stages of ore deposition have been distinguished [36]: (1) feldspar-molybdenite veins with biotite, (2) feldspathic, pegmatitic quartz veins, (3) quartz veins with molybdenite and scheelite (stockwork system), (4) black quartz veins with molybdenite, and (5) polymetallic quartz veins (without molybdenite). Period III produced mainly ankerite and barite-fluorite mineralization. This classification proposed by Ślósarz [36] was adopted for the assignment of various generations of pyrite to the different stages of ore mineralization in the Myszków deposit (Table 1). 
Table 1. Pyrite generations and their characterization.

\begin{tabular}{|c|c|c|c|c|c|c|c|c|}
\hline \multirow[t]{2}{*}{$\begin{array}{c}\text { Pyrite } \\
\text { Generation }\end{array}$} & \multirow{2}{*}{\multicolumn{2}{|c|}{$\begin{array}{l}\text { Stage of Mineralization } \\
\text { (According to Ślósarz, 2001) }\end{array}$}} & \multirow[t]{2}{*}{$\begin{array}{c}\text { Form of } \\
\text { Mineralization }\end{array}$} & \multicolumn{2}{|c|}{$\begin{array}{c}\text { Vein Mineral Assemblage } \\
\text { (Identified by SEM-EDS and } \\
\text { Raman Spectroscopy) }\end{array}$} & \multicolumn{2}{|c|}{$\begin{array}{c}\text { Pyrite-Hosted Solid Inclusion } \\
\text { (Identified by SEM-EDS and } \\
\text { Raman Spectroscopy) }\end{array}$} & \multirow{2}{*}{$\begin{array}{c}\text { Fracture-Filling } \\
\text { Minerals in } \\
\text { Pyrite }\end{array}$} \\
\hline & & & & Gangue & Ore & Gangue & Ore & \\
\hline I-type pyrite & $\begin{array}{c}\text { Early, } \\
\text { skarn-forming }\end{array}$ & - & $\begin{array}{l}\text { Quartz-chlorite- } \\
\text { biotite veins with } \\
\text { magnetite, } \\
\text { molybdenite, } \\
\text { and scheelite }\end{array}$ & $\begin{array}{l}\text { plagioclase, biotite, } \\
\text { chlorite, epidote, } \\
\text { quartz, calcite, } \\
\text { apatite }\end{array}$ & $\begin{array}{c}\text { magnetite, } \\
\text { chalcopyrite, } \\
\text { molybdenite, } \\
\text { ilmenite, scheelite }\end{array}$ & $\begin{array}{l}\text { quartz, chlorite, } \\
\text { plagioclase, biotite }\end{array}$ & $\begin{array}{c}\text { magnetite, chalcopyrite, } \\
\text { molybdenite, } \\
\text { ilmenite, } \\
\text { Bi-tellurosulfides and } \\
\text { tellurides, bismuthinite }\end{array}$ & not observed \\
\hline II-type pyrite & $\begin{array}{c}\text { Main, } \\
\text { hydrothermal }\end{array}$ & $\begin{array}{l}\text { Feldspathic, } \\
\text { pegmatitic } \\
\text { quartz veins }\end{array}$ & Pegmatitic veins & $\begin{array}{c}\text { quartz, } \\
\text { K-feldspars, } \\
\text { calcite, galena }\end{array}$ & $\begin{array}{c}\text { chalcopyrite, } \\
\text { molybdenite, } \\
\text { scheelite, bornite } \\
\text { (veinlets in } \\
\text { chalcopyrite) }\end{array}$ & quartz & $\begin{array}{c}\text { galena, chalcopyrite, } \\
\text { native } \mathrm{Ag}\end{array}$ & chalcopyrite \\
\hline III-type pyrite & $\begin{array}{c}\text { Main, } \\
\text { hydrothermal }\end{array}$ & $\begin{array}{l}\text { Quartz veins, } \\
\text { with } \\
\text { molybdenite } \\
\text { and scheelite }\end{array}$ & Stockwork veins & $\begin{array}{l}\text { quartz, calcite, } \\
\text { K-feldspars }\end{array}$ & $\begin{array}{l}\text { molybdenite, } \\
\text { chalcopyrite, } \\
\text { bornite, scheelite, } \\
\text { REE-bearing } \\
\text { minerals }\end{array}$ & $\begin{array}{l}\text { quartz, } \\
\text { K-feldspars, } \\
\text { K-mica, illite, } \\
\text { apatite }\end{array}$ & $\begin{array}{l}\text { chalcopyrite, galena, } \\
\text { cassiterite, REE-bearing } \\
\text { minerals (monazite, } \\
\text { cerianite), molybdenite, } \\
\text { Bi-tellurides, } \mathrm{Sn}+\mathrm{Cu}, \\
\text { rutile, titanite }\end{array}$ & not observed \\
\hline IV-type pyrite & $\begin{array}{c}\text { Main, } \\
\text { hydrothermal }\end{array}$ & $\begin{array}{l}\text { Polymetallic } \\
\text { quartz }\end{array}$ & Impregnations & - & - & chlorite & $\begin{array}{l}\text { galena, sphalerite, } \\
\text { minerals from } \\
\text { aikinite-group }\end{array}$ & galena, sphalerite \\
\hline V-type pyrite & $\begin{array}{r}\text { Metasomatic py } \\
\text { mineraliz }\end{array}$ & $\begin{array}{l}\text { from different } \\
\text { on stages }\end{array}$ & $\begin{array}{l}\text { Near-vein } \\
\text { mineralization }\end{array}$ & - & - & $\begin{array}{c}\text { quartz, } \\
\text { K-feldspars, } \\
\text { calcite, sericite, } \\
\text { chlorite, albite, } \\
\text { siderite, apatite, } \\
\text { gypsum, clay } \\
\text { minerals }\end{array}$ & $\begin{array}{c}\text { galena, sphalerite, } \\
\text { chalcopyrite, } \\
\text { molybdenite, } \\
\text { REE-bearing minerals } \\
\text { (monazite), Ti-oxides, } \\
\text { Bi-tellurides }\end{array}$ & chalcopyrite \\
\hline
\end{tabular}




\section{Sampling and Methods}

Samples were collected from four boreholes: Myszków PZ-16, Myszków PZ-23, Myszków PZ-18, and Myszków PZ-19. Solid inclusions in pyrite were identified with scanning electron microscopy with energy-dispersive spectroscopy (SEM-EDS) supported by Raman spectroscopy (RS) as a complementary tool. To avoid misleading interpretations, only phases that looked like they were accidentally trapped during crystal growth or daughter minerals within fluid inclusions were analyzed.

The back-scattered electron (BSE) observations were performed on uncoated, polished samples using a Hitachi SU3500 scanning electron microscope in variable pressure (VP) mode. The accelerating voltage was set to $15 \mathrm{kV}$, the working distance was set to $10 \mathrm{~mm}$, and the spot size (probe current) was set to 70 (dimensionless unit provided by SEM software). The chemical composition of minerals was obtained by semi-quantitative analysis with the Thermo Scientific UltraDry Compact EDS Detector.

Raman spectra of pyrite-hosted solid inclusions were recorded on clean cleavage surfaces of the rocks using a Thermo Scientific DXR Raman microscope featuring 10×, $50 \times$, and $100 \times$ magnification objectives. The samples were excited with a $532 \mathrm{~nm}$ laser with power from 10 to $20 \mathrm{~mW}$; exposure time was $3 \mathrm{~s}$, the number of exposures was 10, and the laser focus diameter was approximately $2-1 \mu \mathrm{m}$. The spectra were corrected for background by the sextic polynomial method using OMNIC software.

\section{Results}

Based on morphological and textural features, five generations of pyrite have been distinguished (Table 1). They were attributed to the mineralization stages defined previously by Ślósarz [36] and characterized in terms of the abundance of pyrite-hosted solid inclusions.

The I-type pyrite, Py-I (Figure 2A-D), occurs within the quartz-chlorite-biotite veins together with magnetite, molybdenite, and scheelite. Such mineral association corresponds to the early, skarn-forming stage of mineralization [36]. Pyrite forms anhedral, fractured grains, often intergrown with biotite and magnetite (Figure 2A,B). The main feature of Py-I is its porous texture with clustered pores and abundant mineral inclusions, represented mostly by phases filling veins and forming single nests (i.e., chlorite, magnetite, chalcopyrite; see Table 1). Additionally, Bi-tellurosulfides, tellurides, and bismuthinite occur locally as solid inclusions in pyrite (Figure 2A-D). Bismuthinite forms anhedral (rounded) inclusions up to $200 \mu \mathrm{m}$ in size. Its presence was also confirmed by the Raman micro-spectroscopy, revealing its diagnostic bands found at 238, 260, 184, 169, and $100 \mathrm{~cm}^{-1}$ [42,43] (Figure 3). Moreover, the presence of small bastnaesite-(Ce) inclusions (up to a few microns) rooted in the bismuthinite (Figure 3, Table 2) was proved by active Raman bands at 1095, 286, and $265 \mathrm{~cm}^{-1}$ [44].

The II-type pyrite, Py-II (Figure 4A-D), is found in feldspathic, pegmatitic quartz veins. It forms single, euhedral crystals and aggregates of subhedral to anhedral grains. It hosts numerous chalcopyrite veinlets (Figure 4A-D). Locally, it coexists with latticebladed calcite [45] (Figure 4D). Solid inclusions are mostly represented by gangue phases, i.e., quartz accompanied by chalcopyrite and native Ag (Table 1). There are also numerous voids in the pyrite grains, which may be relics of fluid inclusions or formed as a result of coupled dissolution-reprecipitation processes [46,47].

The III-type pyrite, Py-III (Figure 5A-D), occurs in quartz veins of the stockwork system, accompanied by molybdenite and scheelite. It contains a relatively diversified set of inclusions (Table 1, Figure 5A-D), but their number within the single grain is relatively low. The most common indication of petrogenetic interpretations seems to be the inclusions of cassiterite (Figure 5A), REE-bearing minerals (monazite-(Ce) and cerianite-(Ce)), and rutile (Figures $5 \mathrm{C}$ and $6 \mathrm{~A}$ ). In contrast to pyrite, most of the $\mathrm{TiO}_{2}$ inclusions in associated quartz were identified as anatase (Figure 6B, Table 2). Only occasionally, in the pyrite from the PZ-23 borehole, U-rich anatase with the remnants of xenotime found at its marginal parts (Figure 7C-D) is also found. This inclusion is connected to pyrite-hosted quartz by a thin veinlet. Hence, this inclusion is likely the secondary-originated inclusion, genetically 
related to xenotime with a U-rich rim hosted in the associated quartz (Figure 7A,B). Further investigation of xenotime by Raman micro-spectroscopy revealed the presence of hematite inclusions marked by active Raman bands at 1313, 609, 409, 290, and $223 \mathrm{~cm}^{-1}$ (Figure 8, Table 2) [48,49].
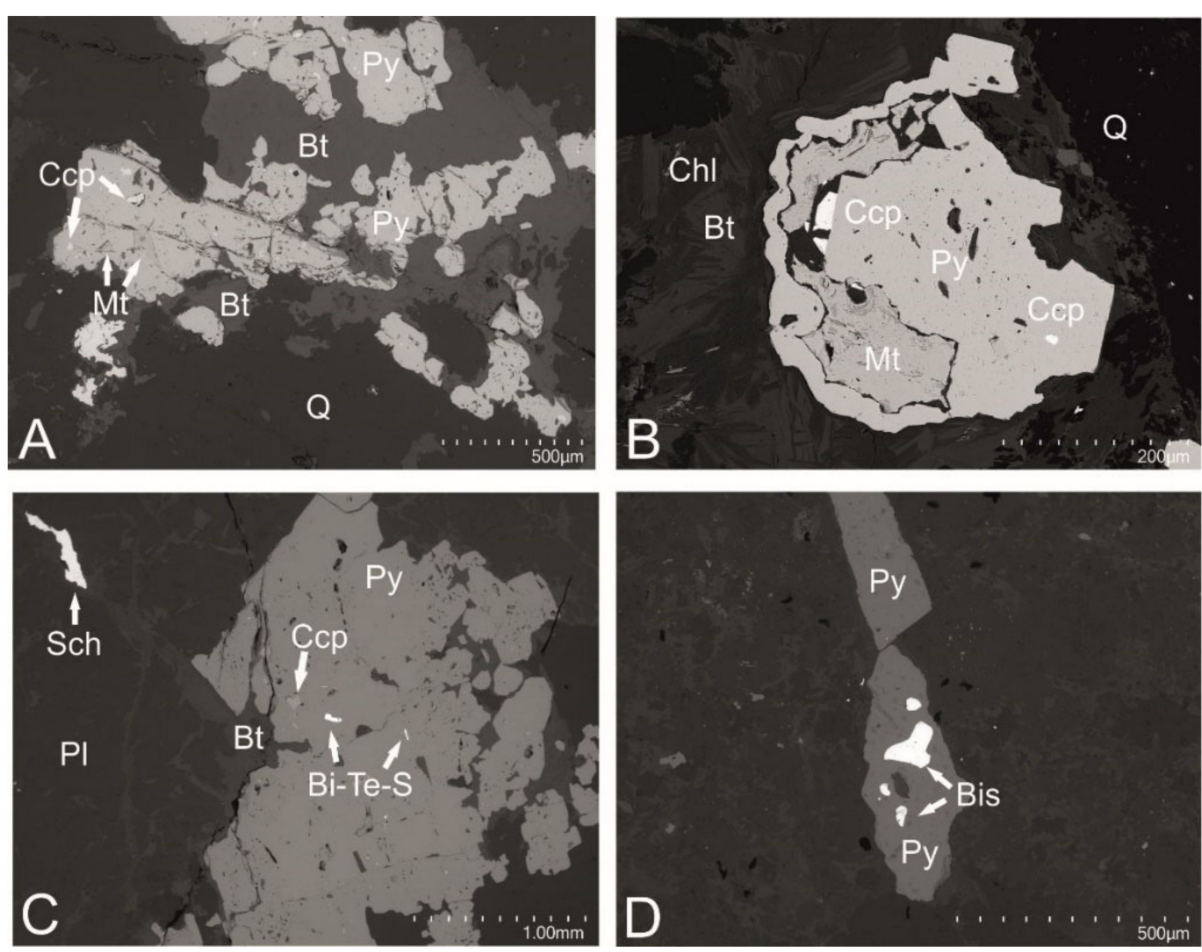

Figure 2. (A-D) SEM back-scattered images of Py-I (early, skarn-forming stage of mineralization). (A) Pyrite intergrown with biotite, (B) Pyrite intergrown with magnetite and associated with biotite and chlorite, (C) Pyrite with inclusions of Bi-tellurosulfides, (D) Pyrite with inclusions of bismuthinite. Abbreviations: Py—pyrite, $\mathrm{Ccp}$ —chalcopyrite, $\mathrm{Bt}$-biotite, $\mathrm{Mt}$-magnetite, Q—quartz, Chl—chlorite, $\mathrm{Pl}$-plagioclase, Sch—scheelite, Bi-Te-S—Bi-tellurosulfides, Bis—bismuthinite.

The IV-type pyrite, Py-IV (Figure 9A-D), occurs as impregnations in metasomatites, representing the polymetallic quartz mineralization stage. It forms euhedral to subhedral grains with a cataclastic texture and numerous microfractures filled with galena and sphalerite. It shows a scarcity of solid inclusions represented by galena, minerals from the aikinite group, and chlorite.

Additionally, metasomatic pyrite (V-type pyrite, Py-V; Figure 10A-D) is very common in the wall rocks of the veins. It is characterized by a porous texture and the presence of numerous solid inclusions, with host rock components such as quartz, K-feldspars, albite, sericite, and barite. The pyrite forms both euhedral and anhedral grains.

Table 2. Inclusions found in pyrite with their diagnostic Raman bands.

\begin{tabular}{ccc}
\hline Mineral & Raman bands $\left[\mathbf{c m}^{-\mathbf{1}}\right]$ & References \\
\hline Anatase & $143,396,515,638$ & {$[50,51]$} \\
Bastnaesite & $181,288,719,1095$ & {$[44]$} \\
Bismuthinite & $100,169,184,238,260,279$ & {$[42,43,52]$} \\
Hematite & s 223, vs $409, \mathrm{~m} 609, \mathrm{vs} 1313$, vs 290 & {$[50]$} \\
Rutile & $143,237,444,610$ & {$[53]$} \\
Xenotime & $381,431,522,610,664,1002,1028,1059,2022$, & {$[54]$} \\
\hline
\end{tabular}




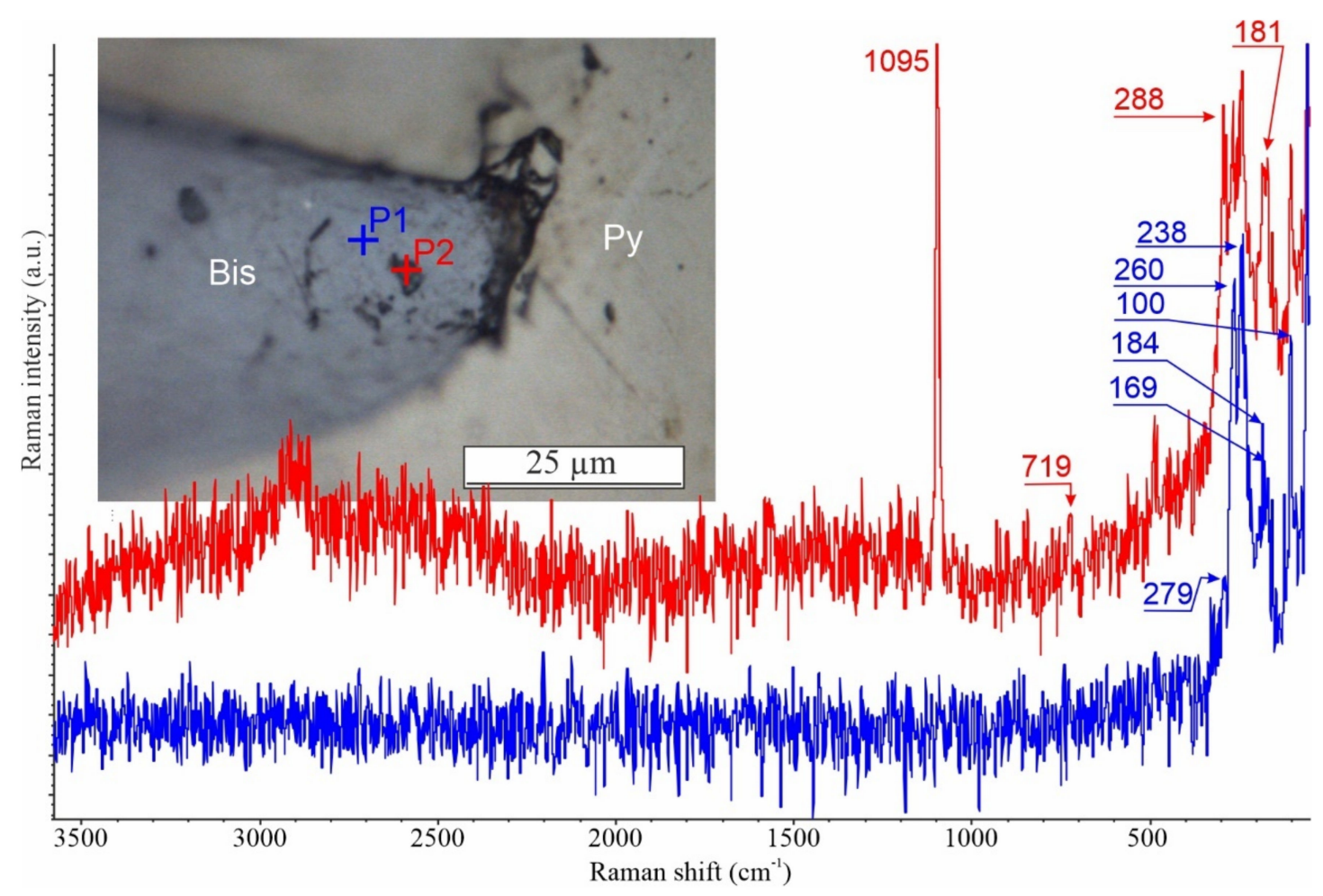

Figure 3. Raman spectra of bismuthinite inclusion in Py-I (blue line) with inclusions of bastnaesite-(Ce) (red line).
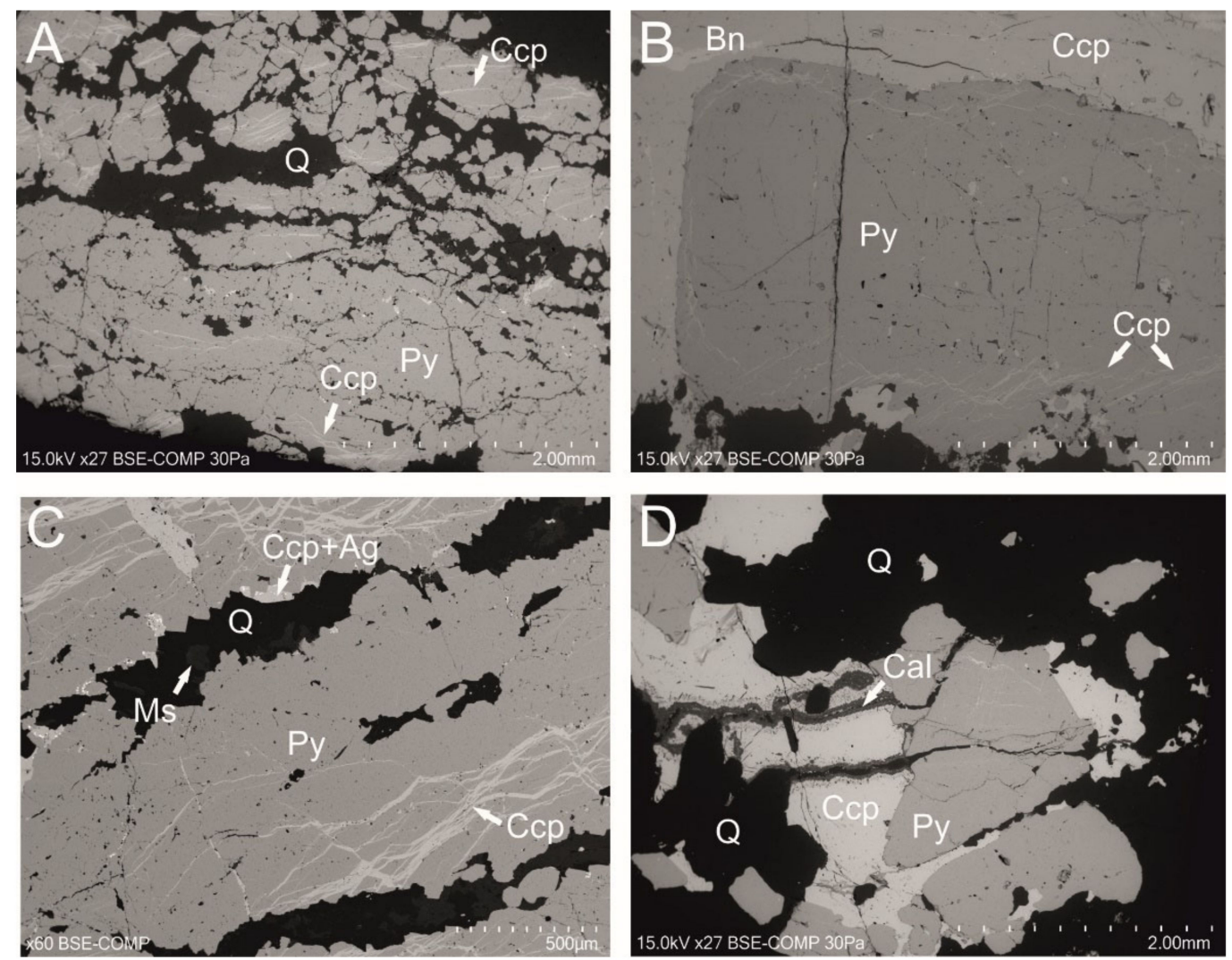

Figure 4. (A-D) SEM back-scattered images of Py-II (feldspathic, pegmatitic quartz veins). (A) Aggregates of subhedral to anhedral grains of Py-II, (B) Chalcopyrite veinlets in Py-II, (C) Py-II with numerous voids (relics of fluid inclusions or dissolution-reprecipitation processes?) and chalcopyrite veinlets, (D) Py-II associated with bladed calcite. Abbreviations: Py—pyrite, Q—quartz, Ccp—chalcopyrite, Ms—muscovite, Cal—calcite. 

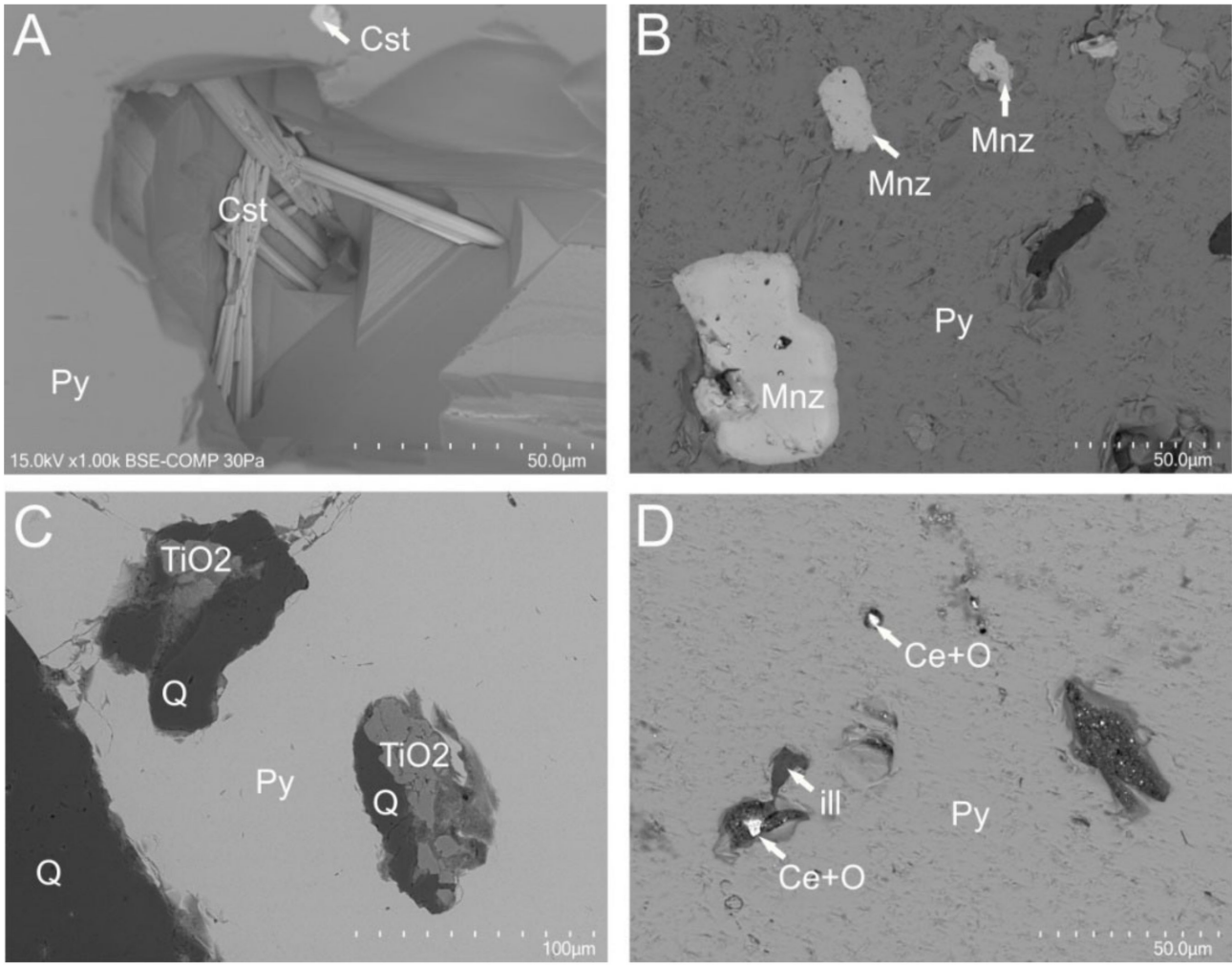

Figure 5. (A-D) SEM back-scattered images of Py-III (quartz veins, with molybdenite and scheelite). (A) cassiterite inclusion trapped by pyrite due to its faster growth, (B) monazite inclusions in Py-III, (C) Inclusions of $\mathrm{TiO}_{2}$ phases in Py-III, (D) Inclusions of cerianite-(Ce) in Py-III. Abbreviations: $\mathrm{Py}$ - pyrite, Cst—cassiterite, $\mathrm{Mnz}$ - monazite-(Ce), $\mathrm{TiO}_{2}$-rutile, $\mathrm{Q}$-quartz, $\mathrm{Ce}+\mathrm{O}$-cerianite-(Ce), ill-illite.

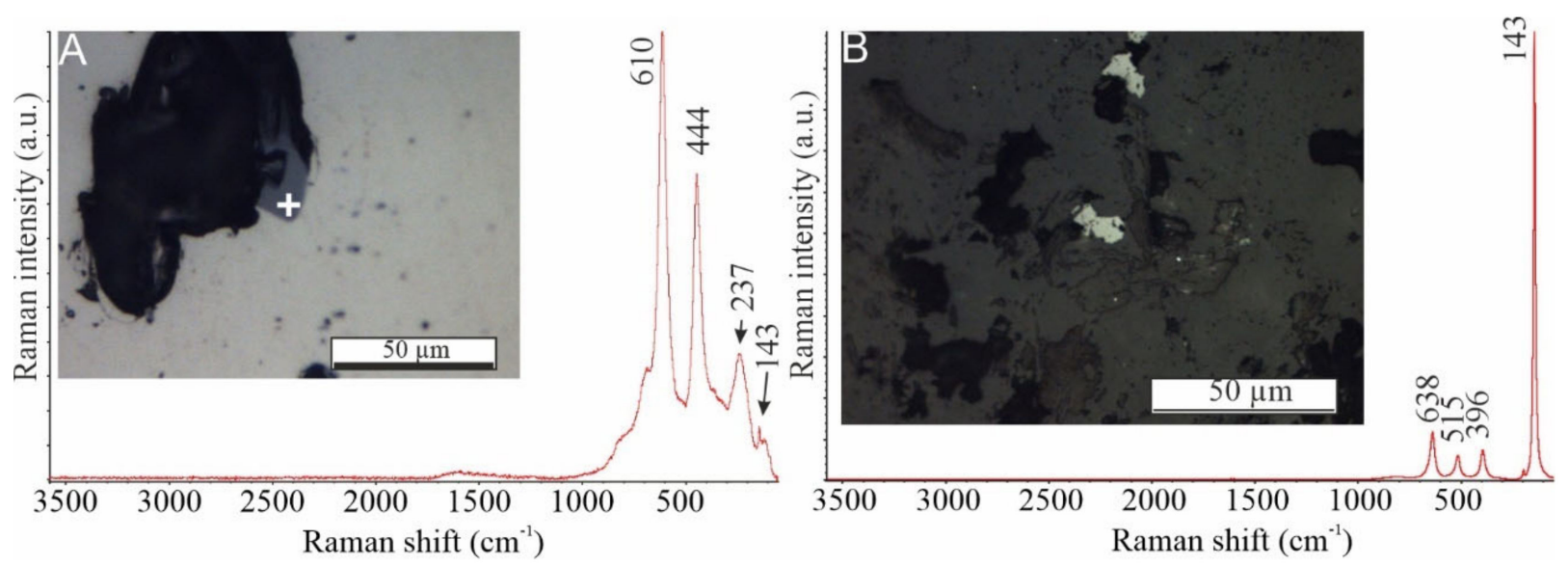

Figure 6. Raman spectra of Ti-bearing inclusions in Py-III: rutile (A); anatase (B). 

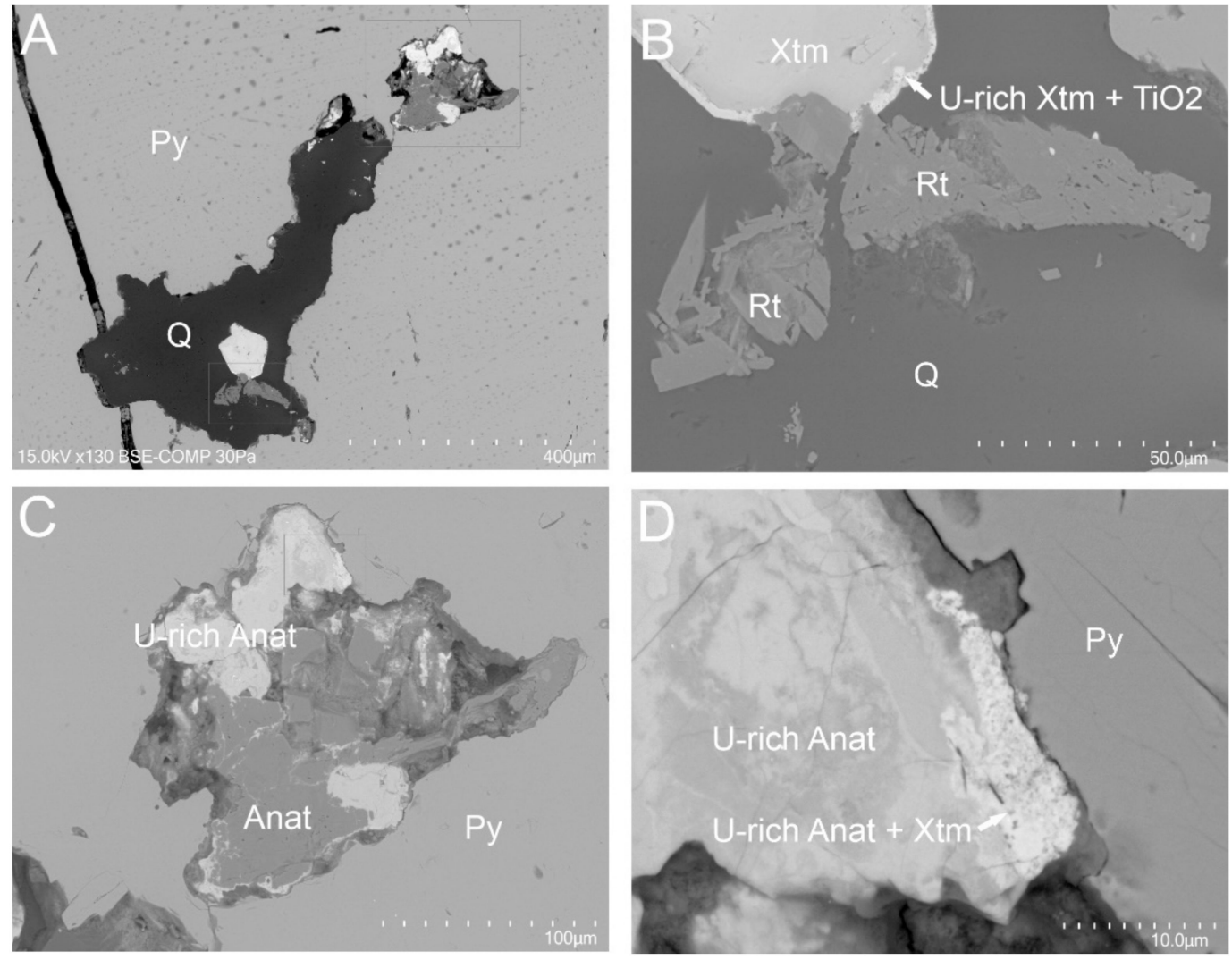

Figure 7. SEM back-scattered images of inclusions hosted in Py-III and associated quartz. (A) Pyrite and associated quartz with inclusions-general view, (B) Inclusion of xenotime with U-rich rim and anatase, (C) Secondary inclusion of anatase in pyrite-general view, (D) Uranium-enriched fragments of anatase inclusion in pyrite.

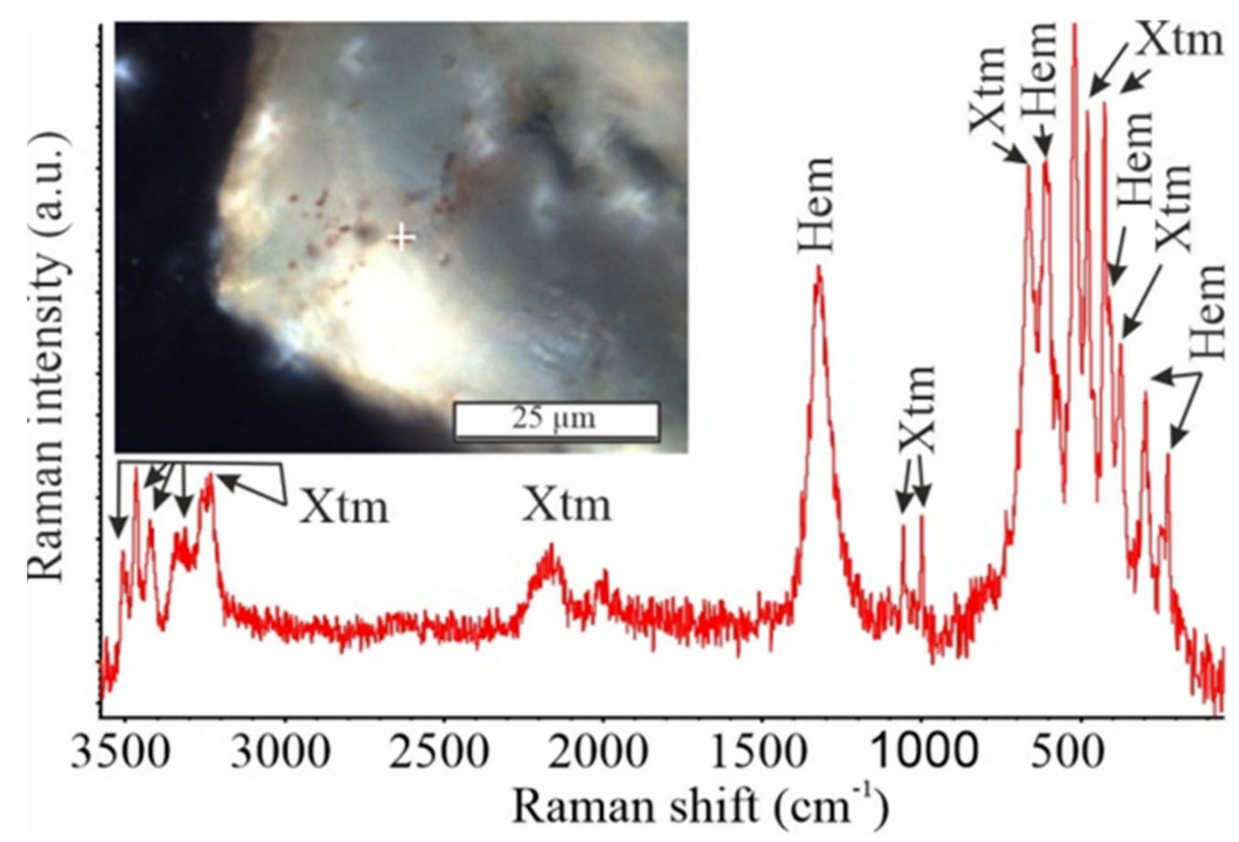

Figure 8. Raman spectra of xenotime hosted in quartz associated with Py-III. Brown inclusions represented by hematite. 

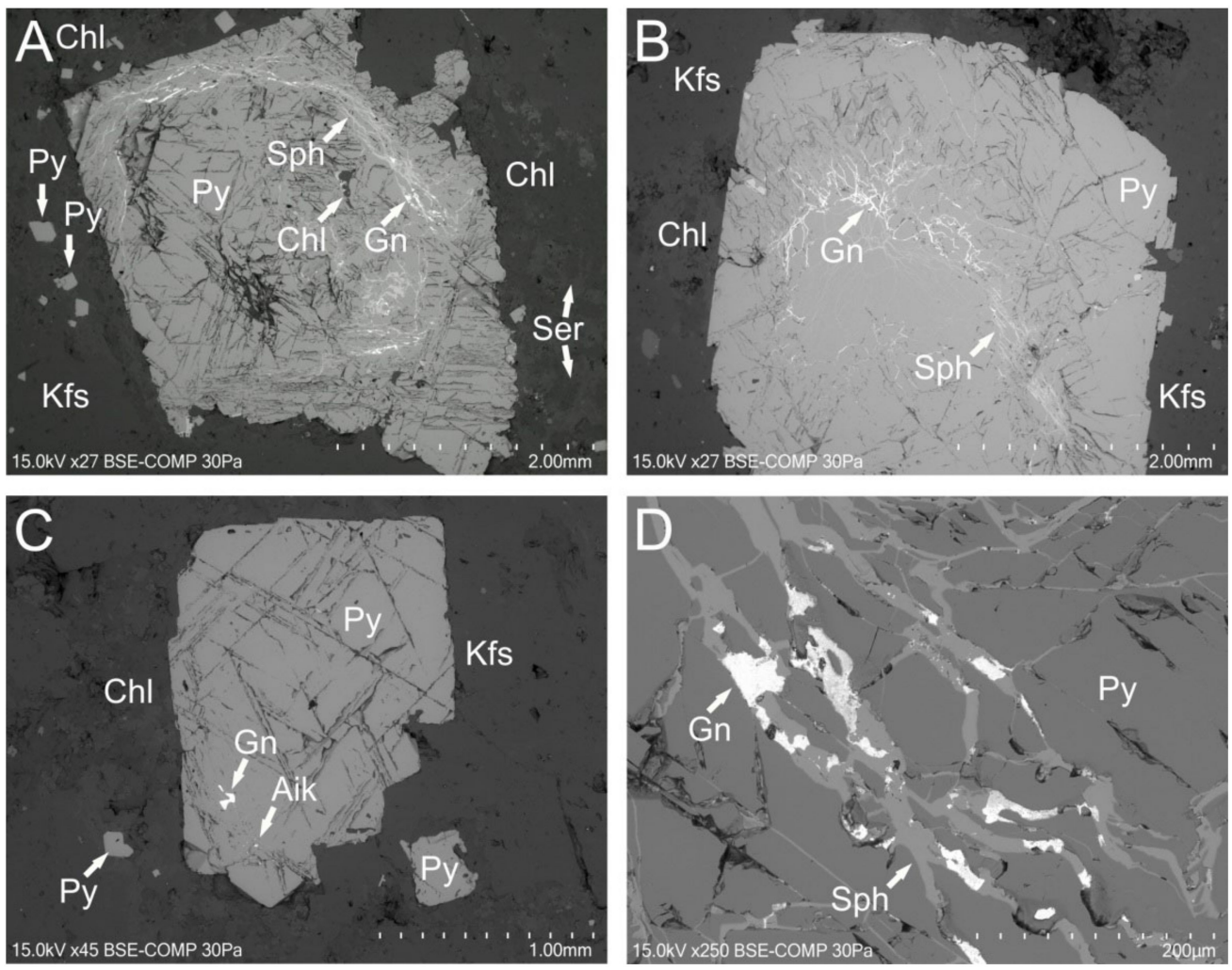

Figure 9. SEM back-scattered images of Py-IV (polymetallic quartz stage). (A,B,D) Cataclastic texture of Py-IV. Veinlets filled with galena and sphalerite, (C) Inclusion of aikinite-group mineral. Abbreviations: Py-pyrite, Chl—chlorite, Kfs-K-feldspars, Ser—sericite, Sph—sphalerite, Gn—galena, Aik—aikinite-group mineral.
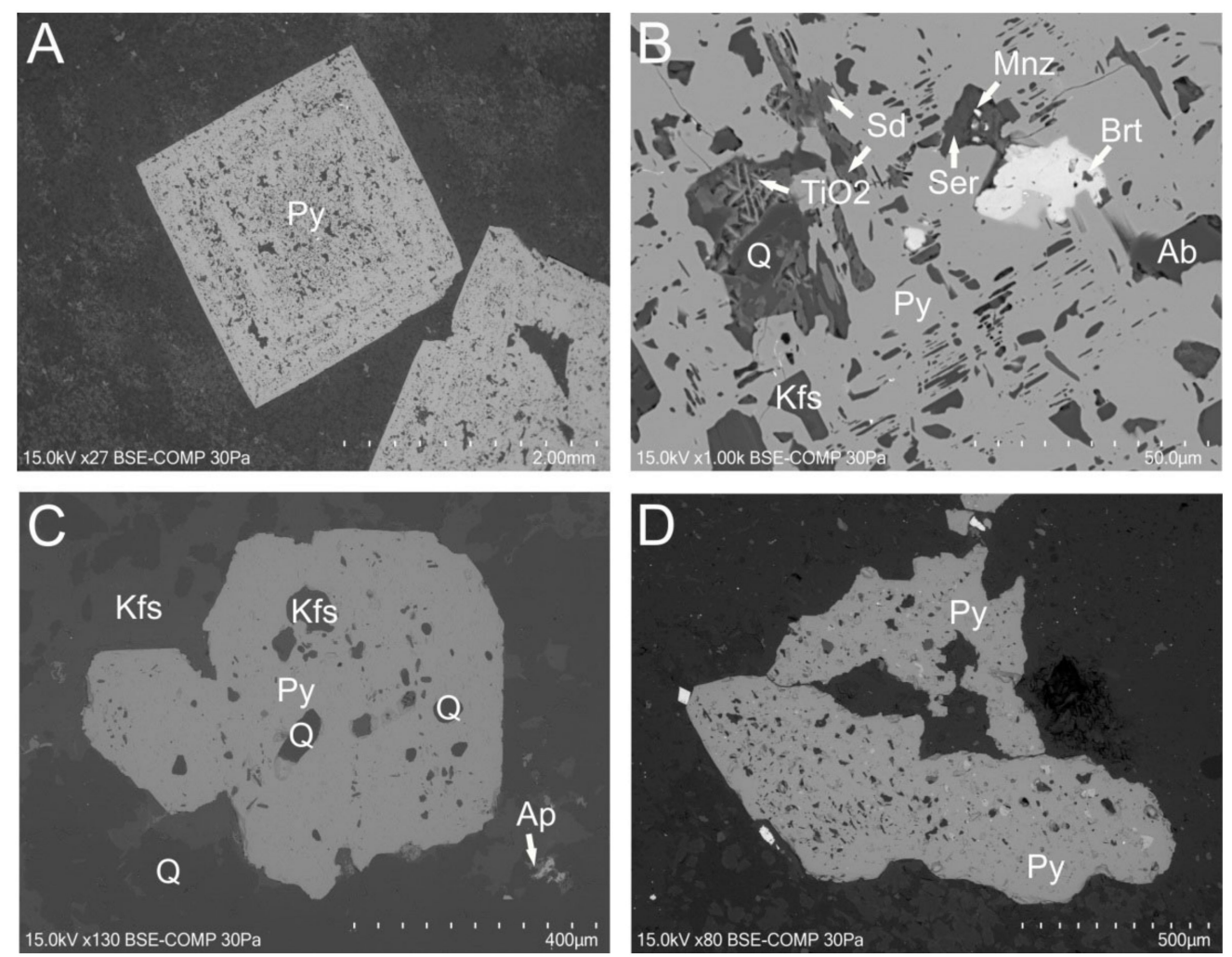

Figure 10. (A-D) SEM back-scattered images of Py-V (metasomatic pyrite). Abbreviations: Py—pyrite, Sd-siderite, Ser-sericite, Brt—barite, $\mathrm{Ab}$-albite, $\mathrm{Kfs}$-K-feldspars, $\mathrm{Q}$ - quartz, $\mathrm{TiO}_{2}$-rutile/anatase, Ap-apatite. 


\section{Discussion}

\subsection{Evidence of Boiling Indicated by Pyrite's Inclusions and Microtextures}

In porphyry systems, metal precipitation pathways might be induced due to the five major processes, including (1) decompression, (2) phase separation (or boiling), (3) cooling, (4) interaction with wall rocks, and (5) mixing with external waters [55]. Among them, boiling is considered to be a very common and effective ore-forming mechanism in many hydrothermal ore deposits [56]. Boiling conditions, caused by drops in the pressure regime lead, to the generation of vapor and hypersaline liquid [57]. As a result, ore and gangue phases come out of the solution once the $\mathrm{pH}$, composition, and ionic strength of the fluid are changed.

Tracers of boiling are believed to be important exploratory guides $[57,58]$. Commonly, boiling horizons are directly associated with zones of the most vigorous mineral deposition [59]. Thus, low metal grades do not preclude the possibility of significant mineralization at greater depths, if some evidence of boiling is observed in the epithermal environment [60]. Moreover, the evidence of boiling could be used to constrain paleodepths, and thus, the level of erosion of the epithermal deposit could be estimated [61,62].

The unequivocal evidence of boiling in the porphyry system could be provided by studying fluid inclusions [63] hosted in gangue minerals (most commonly quartz) or some semi-conducting ore phases suitable for near-infrared microthermometry (i.e., wolframite, As-free pyrite). Boiling conditions are then expressed by the coexistence of high-saline, halite-bearing fluid inclusions and vapor-rich inclusions $[58,60]$. However, even in the absence of fluid inclusion data, some mineralogical and textural indicators can be used to track the boiling conditions, i.e., silica colloform texture or the presence of adularia and bladed calcite $[56,60,64]$, as well as explosion textures in vein quartz and celestite [65], hydrothermal breccias resulting from hydraulic fracturing and pressure release [56], and zonation patterns of trace elements in pyrite [66]. Recently, Román et al. [46] utilized pyrite textures in an active hydrothermal system (geothermal field connected with the Apacheta volcanic complex in Chile) to determine the mineral precipitation pathways. It was shown that porous, inclusion-rich pyrite was indicative of vigorous boiling. In contrast, pyrite formed under gentle boiling to non-boiling conditions contained fewer inclusions owing to more gradual cooling and less abrupt physicochemical variations [46]. Although those observations were made for an active hydrothermal system, they have already been successfully applied in the world-famous mining district, the Cripple Creek Au-Te deposit, Colorado [67].

Abrupt pressure drops during the evolution of the KLFZ were previously captured in quartz-hosted fluid inclusions [68]. However, it remains unclear if boiling was an effective mechanism of metal precipitation and a key factor determining the ore formation in this area. If one adopts the guidelines from Román et al. [46] for boiling phenomena in pyrite to the Myszków deposit, it can be seen that boiling conditions occurred periodically during the crystallization of this mineral. Strong evidence of boiling can be observed within Iand II-type pyrite generations, which exhibit irregular grain edges and areas of clustered micropores. The pyrite grains also host numerous mineral inclusions represented by both gangue (quartz) and ore phases (galena, chalcopyrite, magnetite, tetradymite, and bismuthinite), an abundance of which may suggest vigorous boiling conditions [46]. The close spatial association of lattice-bladed calcite may suggest that the formation of II-type pyrite was synchronous with calcite deposition. Subsequently, III-type pyrite probably formed under gentle to non-boiling conditions, as indicated by scarce mineral inclusions and the homogenous texture formed during more stable physicochemical conditions (Román et al., 2019). In turn, the presence of inclusions of xenotime with U-rich rims within coexisting quartz could support the theory that its its host formed under boiling conditions. The zonation pattern of uranium within xenotime points toward an abrupt change of salinity and the composition of mineralizing fluids. McNaughton and Rasmussen [69] noted that uranium enrichment in xenotime is connected to high-salinity ore fluids. Hence, the variations in fluid salinity could result from the boiling of hydrothermal fluid [57]. 
IV-type pyrite seems to be deposited under relatively steady physicochemical conditions due to the scarcity of mineral inclusions and its euhedral shape. Finally, Py-V, due to its extreme porous texture, has been excluded from the discussion. Its metasomatic origin is evidenced by its location around fluid pathways and the domination of inclusions made of host rock material [70].

Hence, based on our observations it is found that boiling events occurred during the evolution of the KLFZ. Sudden pressure changes leading to boiling could result from several mechanisms, e.g., the upward passage of magma from a tight host rock to a broken host rock, the progressive crystallization of anhydrous minerals, the tumescence of overlying rocks above an advancing magma column, and the resulting fracturing from these scenarios [57]. The progressive crystallization of the intrusion into a tectonically active area accompanied by fracturing could be the most probable scheme in the case of the Myszków Mo- $\mathrm{Cu}-\mathrm{W}$ deposit. If so, the emplacement of ore bodies should be restricted to depths of less than $2 \mathrm{~km}$ as boiling of solutions in the crust is likely related to shallow environments [71]. The presence of boiling during some mineralization stages might also indicate that the distal zones as far as several kilometers away from the causative porphyry should be searched for Au carriers [72]. Simultaneously, boiling does not seem to be the main factor that controlled the precipitation of pyrite during the main, hydrothermal stage of mineralization; however, it could still have caused the increase of potential fluids in the ore. In the case of the youngest episode of fluid activity, where pyrite does not show tracers of boiling, precipitation of this mineral might result from simple cooling or a $\mathrm{pH}$ increase during wall-rock alteration. However, due to the limited range of samples, it may not have been possible to trace all boiling horizons. Further studies are thus still needed, especially with NIR microthermometry as a key technique.

\subsection{Physicochemical Conditions of Mineralizing Fluids}

An ideal way of assessing the properties of ore-forming solutions directly is the use of NIR microthermometry of fluid inclusions hosted in opaque ore phases [73]. However, minerals of very low bandgap energy are currently excluded from NIR microthermometric investigations (e.g., galena, As-bearing pyrite, chalcopyrite) due to technological restrictions (i.e., limited spectral range of NIR microscopes) [74]. Potentially, As-free pyrite is a good candidate for NIR microthermometry, although the transparency of this mineral to NIR radiation shows extreme variations in response to small compositional changes in Co and $\mathrm{Ni}$ content. Another problem is the number of fluid inclusions in some sulfides. Pyrite often does not contain any fluid inclusions that can be analyzed [73]. Thus, successful application of NIR microthermometry is not always possible and precipitation pathways of ore minerals must be inferred from the associated gangue phases. However, that textural evidence of the co-existence of two minerals might be ambiguous and does not always reflect the same fluid conditions in terms of both homogenization temperatures and chemical composition [75]. Hence, in this case, some petrogenetic implications may be obtained from the number and set of solid inclusions hosted in ore minerals, which are mostly of primary origin and thus reflect the physicochemical conditions of mineralizing fluids.

Pyrite originating from different stages of the evolution of the Myszków deposit contains solid inclusions, which might be interpreted as accidentally enclosed within host crystals due to their faster growth or as daughter minerals precipitated from the material trapped in the inclusions [76]. Thus, some of them could be used as proxy indicators of ore-forming processes and related fluid circulation. For example, the occurrence of Sn (as cassiterite inclusions) in the III-type pyrite may indicate hot $\left(300-400{ }^{\circ} \mathrm{C}\right)$, acidic, and reducing fluids responsible for the ore formation during the stockwork stage of mineralization [77]. However, the temperature of ore-forming fluids could have been even higher locally, as evidenced by the inclusions of rutile, observed in pyrites taken from boreholes located near the central part of the ore body. Rutile associated with porphyry copper deposits has been mainly formed at temperatures between 400 and $700{ }^{\circ} \mathrm{C}$ and 
pressures of a few hundred MPa [78]. If so, lateral zoning of temperature conditions of pyrite precipitation could potentially be used for vectoring economic-grade mineralization.

The presence of rutile inclusions in pyrite and the predominance of a low-temperature polymorph of $\mathrm{TiO}_{2}$ (anatase) in the associated quartz indicate that some temperature gap between the precipitation of gangue minerals $\left(360-240{ }^{\circ} \mathrm{C}\right)$ [36] and ores might exist. Additionally, the redox conditions during the precipitation of quartz were mostly oxidizing as evidenced by the existence of xenotime inclusions with hematite inserts. The coexistence of secondary REE minerals along with the sulfides also points toward changes in redox conditions with time. Quite recently, Pal et al. [79] noted that the consumption of sulfur by chalcophile elements to form chalcopyrite and pyrite in the veins destabilizes REE-sulfate complexes transported by primarily oxidizing fluids and causes the precipitation of REE phases in the vicinity of sulfides. It is not certain whether such a scenario could be the case of the Myszków deposit, but the significant fluctuations in the physicochemical conditions of mineralizing fluids seem to occur during the formation of stockworks.

The I-type pyrite probably crystallized over a wide range of temperatures. Some pyrite grains occur in close spatial association with biotite and magnetite and host inclusions of these minerals. Hydrothermal biotite and magnetite are stable at a temperature higher than $450{ }^{\circ} \mathrm{C}$ [80] and such conditions probably also reflect the crystallization environment of pyrite. However, the crystallization of pyrite had continued until the fluids became much cooler, as evidenced by the presence of grains containing inclusions of Bi-minerals (e.g., bismuthinite).

The IV-type pyrite probably crystallized at a lower temperature range, as manifested by the presence of pyrite-hosted inclusions of aikinite-group minerals, which form at about $300{ }^{\circ} \mathrm{C}[81,82]$. In this case, pyrite-hosted solid inclusions provided quite a good approximation to microthermometric results from co-existing gangue phases [36,68], according to which ores were formed from fluids at a temperature ranging from $298^{\circ} \mathrm{C}$ to $275^{\circ} \mathrm{C}$. A well-developed cataclastic texture of IV-type pyrite also indicates medium-temperature conditions (below $300^{\circ} \mathrm{C}$ ) [83]. It is probable that some tectonic movements, which caused the dislocation deformation of pyrite, were simultaneous with the ore deposition and remobilization of the more ductile galena and sphalerite into numerous microfractures.

Further constraints on precipitation pathways of pyrite from the KLFZ should be obtained with NIR microthermometry, especially since it has a good potential for this method (low impurities of Co, Ni, and As [36], and the presence of micropores (relicts of fluid inclusions?)). Moreover, bulk pyrite's geochemistry and the geochemistry of fluid inclusions (i.e., due to the LA-ICP-MS) should be implemented as a complementary tool to track composition changes of mineralizing fluids, $\mathrm{pH}$, and redox conditions, which control the metal-ligand solubility [84].

\section{Conclusions}

1. Different generations of pyrite from the Myszków $\mathrm{Mo}-\mathrm{Cu}-\mathrm{W}$ deposit exhibit diverse mineral inclusions. This points toward physicochemical changes that occurred as the ore-forming system evolved with time.

2. The number and set of solid inclusions hosted in pyrite indicate precipitation from a vigorous boiling system during the early, skarn-forming stage of mineralization and the formation of pegmatitic veins. Younger episodes of fluid discharges tended to take place under gentle to non-boiling conditions.

3. Solid-inclusion assemblages hosted in pyrite from a stockwork system (i.e., rutile, cassiterite, REE-bearing minerals) and in associated quartz (i.e., anatase, xenotime with hematite inserts) indicate different fluid conditions (temperature, redox conditions) during the precipitation of ores and gangue phases. Moreover, the spatial differentiation of solid-inclusion assemblages in pyrites suggest some zonality of their crystallization environment. Thus, pyrite and its inclusions could be good tracers for vectoring horizons with the most vigorous mineral deposition. However, further 
studies are needed to support this conclusion, especially with NIR microthermometry as a key technique.

Author Contributions: B.N., M.D.-S. and T.T. designed and performed the experiments, interpreted the data, wrote the paper, and prepared the figures and photographs. P.D. performed the experiments and prepared the photographs. R.H. and M.M. interpreted the data, substantively revised the first version of the manuscript, and prepared the figures. All authors have read and agreed to the published version of the manuscript.

Funding: The work was financially supported by the National Science Centre, Poland (project no. 2020/04/X/ST10/00572) and AGH University of Science and Technology (16.16.140.315).

Institutional Review Board Statement: Not applicable.

Informed Consent Statement: Not applicable.

Data Availability Statement: Not applicable.

Acknowledgments: We thank two anonymous reviewers for their constructive comments and the editor for handling the paper.

Conflicts of Interest: The authors declare no conflict of interest.

\section{References}

1. Reich, M.; Deditius, A.; Chryssoulis, S.; Li, J.W.; Ma, C.Q.; Parada, M.A.; Barra, F.; Mittermayr, F. Pyrite as a record of hydrothermal fluid evolution in a porphyry copper system: A SIMS/EMPA trace element study. Geochim. Cosmochim. Acta 2013, $104,42-62$. [CrossRef]

2. Huston, D.L.; Sie, S.H.; Suter, G.F.; Cooke, D.R.; Both, R.A. Trace elements in sulfide minerals from eastern Australian volcanichosted massive sulfide deposits: Part I. Proton microprobe analyses of pyrite, chalcopyrite, and sphalerite, and part II. Selenium levels in pyrite: Comparison with $\delta 34$ S values and impli. Econ. Geol. 1995, 90, 1167-1196. [CrossRef]

3. Basori, M.B.I.; Gilbert, S.; Large, R.R.; Zaw, K. Textures and trace element composition of pyrite from the Bukit Botol volcanichosted massive sulphide deposit, Peninsular Malaysia. J. Asian Earth Sci. 2018, 158, 173-185. [CrossRef]

4. Leach, D.L.; Taylor, R.D.; Fey, D.L.; Diehl, S.F.; Saltus, R.W. A deposit model for Mississippi Valley-type lead-zinc ores. In Chapter A of Mineral Deposit Models for Resource Assessment; USGS: Reston, VA, USA, 2010; Volume 107.

5. Ho, S.E.; McNaughton, N.J.; Groves, D.I. Criteria for determining initial lead isotopic compositions of pyrite in Archaean lode-gold deposits: A case study at Victory, Kambalda, Western Australia. Chem. Geol. 1994, 111, 57-84. [CrossRef]

6. Yang, J.H.; Zhou, X.H. Rb-Sr, Sm-Nd, and Pb isotopes systematics of pyrite: Implications for the age and genesis of lode gold deposits. Geology 2002, 29, 711-714. [CrossRef]

7. Shikazono, N. Precipitation mechanisms of barite in sulfate-sulfide deposits in back-arc basins. Geochim. Cosmochim. Acta 1994, 58, 2203-2213. [CrossRef]

8. Kullerud, G.; Yoder, S. Pyrite stability relations in the Fe-S system. Econ. Geol. 1959, 54, 533-572. [CrossRef]

9. Djon, M.L.N.; Barnes, S.J. Changes in sulfides and platinum-group minerals with the degree of alteration in the Roby, Twilight, and High Grade Zones of the Lac des Iles Complex, Ontario, Canada. Miner. Depos. 2012, 47, 875-896. [CrossRef]

10. Lindaas, S.E.; Kulis, J.; Campbell, A.R. Near-infrared observation and microthermometry of pyrite-hosted fluid inclusions. Econ. Geol. 2002, 97, 603-618. [CrossRef]

11. Large, R.R.; Maslennikov, V.V.; Robert, F.; Danyushevsky, L.V.; Chang, Z. Multistage sedimentary and metamorphic origin of pyrite and gold in the Giant Sukhoi log deposit, Lena Gold Province, Russia. Econ. Geol. 2007, 102, 1233-1267. [CrossRef]

12. Large, R.R.; Danyushevsky, L.; Hollit, C.; Maslennikov, V.; Meffre, S.; Gilbert, S.; Bull, S.; Scott, R.; Emsbo, P.; Thomas, H.; et al. Gold and Trace Element Zonation in Pyrite Using a Laser Imaging Technique: Implications for the Timing of Gold in Orogenic and Carlin-style Sediment-Hosted Deposits. Econ. Geol. 2009, 104, 635-668. [CrossRef]

13. Dmitrijeva, M.; Cook, N.J.; Ehrig, K.; Ciobanu, C.L.; Metcalfe, A.V.; Kamenetsky, M.; Kamenetsky, V.S.; Gilbert, S. Multivariate statistical analysis of trace elements in pyrite: Prediction, bias and artefacts in defining mineral signatures. Minerals 2020, 10, 61. [CrossRef]

14. Deditius, A.P.; Utsunomiya, S.; Reich, M.; Kesler, S.E.; Ewing, R.C.; Hough, R.; Walshe, J. Trace metal nanoparticles in pyrite. Ore Geol. Rev. 2011, 42, 32-46. [CrossRef]

15. Deditius, A.P.; Reich, M.; Kesler, S.E.; Utsunomiya, S.; Chryssoulis, S.L.; Walshe, J.; Ewing, R.C. The coupled geochemistry of Au and As in pyrite from hydrothermal ore deposits. Geochim. Cosmochim. Acta 2014, 140, 644-670. [CrossRef]

16. Mancano, D.P.; Campbell, A.R. Microthermometry of enargite-hosted fluid inclusions from the Lepanto, Philippines, highsulfidation Cu-Au deposit. Geochim. Cosmochim. Acta 1995, 59, 3909-3916. [CrossRef]

17. Lüders, V.; Ziemann, M. Possibilities and limits of infrared light microthermometry applied to studies of pyrite-hosted fluid inclusions. Chem. Geol. 1999, 154, 169-178. [CrossRef] 
18. Kouzmanov, K.; Bailly, L.; Ramboz, C.; Rouer, O.; Bény, J.M. Morphology, origin and infrared microthermometry of fluid inclusions in pyrite from the Radka epithermal copper deposit, Srednogorie zone, Bulgaria. Miner. Depos. 2002, 37, 599-613. [CrossRef]

19. Cook, N.J.; Ciobanu, C.L.; Mao, J. Textural control on gold distribution in As-free pyrite from the Dongping, Huangtuliang and Hougou gold deposits, North China Craton (Hebei Province, China). Chem. Geol. 2009, 264, 101-121. [CrossRef]

20. Cook, N.J.; Ciobanu, C.L.; Meria, D.; Silcock, D.; Wade, B. Arsenopyrite-pyrite association in an orogenic gold ore: Tracing mineralization history from textures and trace elements. Econ. Geol. 2013, 108, 1273-1283. [CrossRef]

21. Voute, F.; Hagemann, S.G.; Evans, N.J.; Villanes, C. Sulfur isotopes, trace element, and textural analyses of pyrite, arsenopyrite and base metal sulfides associated with gold mineralization in the Pataz-Parcoy district, Peru: Implication for paragenesis, fluid source, and gold deposition mechanisms. Miner. Depos. 2019, 54, 1077-1100. [CrossRef]

22. Mikulski, S.Z.; Markowiak, M.; Zieliński, G.; Giro, L. New data on tellurium-bismuth mineralization from the Myszków and Mysłów regions in the contact zone of the Małopolska Block with the Upper Silesia Block. Biul. Panstw. Inst. Geol. 2015, 465, 99-122. [CrossRef]

23. Buła, Z. The lower palaeozoic of upper Silesia and West Małopolska. Pr. Państwowego Inst. Geol. 2000, 171, 1-89.

24. Buła, Z.; Zaba, J.; Habryn, R. Tectonic subdivison of Poland: Southern Poland (Upper Silesian Block and Małopolska Block). Prz. Geol. 2008, 56, 912-920.

25. Finger, F.; Hanžl, P.; Pin, C.; von Quadt, A.; Steyrer, H.P. The Brunovistulian: Avalonian Precambrian sequence at the eastern end of the Central European Variscides? Geol. Soc. Spec. Publ. 2000, 179, 103-112. [CrossRef]

26. Zelaźniewicz, A.; Buła, Z.; Fanning, M.; Seghedi, A.; Żaba, J. More evidence on Neoproterozoic terranes in Southern Poland and southeastern Romania. Geol. Q. 2009, 53, 93-124.

27. Belka, Z.; Valverde-Vaquero, P.; Dörr, W.; Ahrendt, H.; Wemmer, K.; Franke, W.; Schäfer, J. Accretion of first Gondwana-derived terranes at the margin of Baltica. Geol. Soc. Spec. Publ. 2002, 201, 19-36. [CrossRef]

28. Nawrocki, J.; Dunlap, J.; Pecskay, Z.; Krzemiński, L.; Zylińska, A.; Fanning, M.; Kozłowski, W.; Salwa, S.; Szczepanik, Z.; Trela, W. Late Neoproterozoic to Early Palaeozoic palaoegeography of the Holy Cross Mountains (Central Europe): An integrated approach. J. Geol. Soc. London 2007, 164, 405-423. [CrossRef]

29. Habryn, R.; Krzemińska, E.; Krzemiński, L.; Markowiak, M.; Zieliński, G. Detrital zircon age data from the conglomerates in the upper silesian and małopolska blocks, and their implications for the pre-Variscan tectonic evolution (S Poland). Geol. Q. 2020, 64, 321-341. [CrossRef]

30. Matte, P. Tectonics and plate tectonics model for the Variscan belt of Europe. Tectonophysics 1986, 126, 329-374. [CrossRef]

31. McCann, T.; Pascal, C.; Timmerman, M.J.; Krzywiec, P.; López-Gómez, J.; Wetzel, A.; Krawczyk, C.M.; Rieke, H.; Lamarche, J. Post-Variscan (end Carboniferous-Early Permian) basin evolution in Western and Central Europe. In European Lithosphere Dynamics; Gee, D.G., Stephenson, R.A., Eds.; Geological Society: London, UK, 2006; Volume 32, pp. 355-388. ISBN 1862392129.

32. Wolfgang, F. The Variscan orogen in Central Europe: Construction and collapse. In European Lithosphere Dynamics; Gee, D.C., Stephenson, R.A., Eds.; Geological Society: London, UK, 2006; pp. 333-343.

33. Mazur, S.; Aleksandrowski, P.; Turniak, K.; Krzemiński, L.; Mastalerz, K.; Górecka-Nowak, A.; Kurowski, L.; Krzywiec, P.; Zelaźniewicz, A.; Fanning, M.C. Uplift and late orogenic deformation of the Central European Variscan belt as revealed by sediment provenance and structural record in the Carboniferous foreland basin of western Poland. Int. J. Earth Sci. 2010, 99, 47-64. [CrossRef]

34. Słaby, E.; Breitkreuz, C.; Zaba, J.; Domańska-Siuda, J.; Gaidzik, K.; Falenty, K.; Falenty, A. Magma generation in an alternating transtensional-transpressional regime, the Kraków-Lubliniec Fault Zone, Poland. Lithos 2010, 119, 251-268. [CrossRef]

35. Zelaźniewicz, A.; Oberc-Dziedzic, T.; Fanning, C.M.; Protas, A.; Muszyński, A. Late Carboniferous-early Permian events in the Trans-European Suture Zone: Tectonic and acid magmatic evidence from Poland. Tectonophysics 2016, 675, 227-243. [CrossRef]

36. Ślósarz, J. Mineralogical characteristics of the mineralization. In Palaeozoic Porphyry Molybdenum-Ungsten Deposit in the Myszków area, Southern Poland; Podemski, M., Ed.; Polish Geological Institute, Special Papers: Warsaw, Poland, 2001; Volume 6, pp. 1-88.

37. Mikulski, S.Z.; Williams, I.S.; Markowiak, M. Carboniferous-Permian magmatism and Mo-Cu (W) mineralization in the contact zone between the Małopolska and Upper Silesia Blocks (south Poland): An echo of the Baltica-Gondwana collision. Int. J. Earth Sci. 2019, 108, 1467-1492. [CrossRef]

38. Ślósarz, J. Stages and zonality of ore mineralization in Paleozoic rocks of the environs of Myszków. Ann. Soc. Geol. Pol. 1985, $53,267-288$.

39. Truszel, M.; Karwowski, Ł.; Lasoń, K.; Markiewicz, J.; Żaba, J. Magmatism and metamorphism of the Kraków-Lubliniec tectonic zone as a clue to the occurrence of polymetallic deposits. Biul. Inst. Geol. 2006, 418, 55-103.

40. Markowiak, M. Description of ore mineralization against the background of thermal-metasomatic alterations of rocks in the Zarki-Kotowice area. Pr. Panstw. Inst. Geol. 2015, 203, 436-443.

41. Buła, Z.; Byś, I.; Florek, R.H.R.; Jachowicz, M.; Kwarcinski, J.; Laskowicz, R.; Liszka, B.; Madej, K.; Maksym, A.; Markowiak, M.; et al. Atlas Geologiczno-Strukturalny Paleozoicznego Podłoża Karpat Zewnętrznych I Zapadliska Przedkarpackiego; Bula, Z.H.R., Ed.; Państwowy Instytut Geologiczny: Warsaw, Poland, 2008.

42. Kharbish, S.; Libowitzky, E.; Beran, A. Raman spectra of isolated and interconnected pyramidal XS3 groups (X = Sb,Bi) in stibnite, bismuthinite, kermesite, stephanite and bournonite. Eur. J. Mineral. 2009, 21, 325-333. [CrossRef] 
43. Buzatu, A.; Damian, G.; Buzgar, N.; Andráš, P.; Apopei, A.I.; Maftei, A.E.; Milovská, S. Structural key features of bismuth and Sb-As sulfosalts from hydrothermal deposits-micro-Raman spectrometry. Vib. Spectrosc. 2017, 89, 49-56. [CrossRef]

44. Frost, R.L.; Dickfos, M.J. Recent Advances in linear and nonlinear Raman spectroscopy I. J. Raman Spectrosc. 2007, 38, 1516-1522. [CrossRef]

45. Moncada, D.; Mutchler, S.; Nieto, A.; Reynolds, T.J.; Rimstidt, J.D.; Bodnar, R.J. Mineral textures and fluid inclusion petrography of the epithermal Ag-Au deposits at Guanajuato, Mexico: Application to exploration. J. Geochemical Explor. 2012, $114,20-35$. [CrossRef]

46. Román, N.; Reich, M.; Leisen, M.; Morata, D.; Barra, F.; Deditius, A.P. Geochemical and micro-textural fingerprints of boiling in pyrite. Geochim. Cosmochim. Acta 2019, 246, 60-85. [CrossRef]

47. Williams-Jones, A.E.; Bowell, R.J.; Migdisov, A.A. Gold in solution. Elements 2009, 5, 281-287. [CrossRef]

48. Hanesch, M. Raman spectroscopy of iron oxides and (oxy)hydroxides at low laser power and possible applications in environmental magnetic studies. Geophys. J. Int. 2009, 177, 941-948. [CrossRef]

49. Marshall, C.P.; Marshall, A.O. Raman Hyperspectral Imaging of Microfossils: Potential Pitfalls. Astrobiology 2013, 13, 920-931. [CrossRef]

50. Frezzotti, M.L.; Tecce, F.; Casagli, A. Raman spectroscopy for fluid inclusion analysis. J. Geochemical Explor. 2012, 112, 1-20. [CrossRef]

51. Andò, S.; Garzanti, E. Raman spectroscopy in heavy-mineral studies. Geol. Soc. London Spec. Publ. 2014, 386, 395-412. [CrossRef]

52. Buzatu, A.; Damian, G.; Dill, H.G.; Buzgar, N.; Apopei, A.I. Mineralogy and geochemistry of sulfosalts from Baia Sprie ore deposit (Romania)—New bismuth minerals occurrence. Ore Geol. Rev. 2015, 65, 132-147. [CrossRef]

53. Swamy, V.; Muddle, B.C.; Dai, Q. Size-dependent modifications of the Raman spectrum of rutile TiO2. Appl. Phys. Lett. 2006, 89, 163118. [CrossRef]

54. Lafuente, B.; Downs, R.T.; Yang, H.; Stone, N. The power of databases: The RRUFF project. In Highlights in Mineralogical Crystallography.; Armbruster, T., Danisi, R.M., Eds.; De Gruyter: Berlin, Germany, 2015; pp. 1-30.

55. Kouzmanov, K.; Pokrovski, G.S.; Hedenquist, J.W.; Harris, M.; Camus, F. Hydrothermal controls on metal distribution in porphyry $\mathrm{Cu}(-\mathrm{Mo}-\mathrm{Au})$ systems. Soc. Econ. Geol. Spec. Publ. 2012, 16, 573-618.

56. Hedenquist, J.W.; Arribas, A.R.; Gonzalez-Urien, E. Exploration for Epithermal Gold Deposits. Rev. Econ. Geol. 2000, 13, $245-277$.

57. Cunningham, C.G. Pressure gradients and boiling as mechanisms for localization ore in porphyry system. J. Res. U.S. Geol. Surv. 1978, 6, 745-754.

58. Nash, J.T. Fluid-Inclusion Petrology: Data from Porphyry Copper Deposits and Applications to Exploration; No 907; US Government Printing Office: Washington, DC, USA, 1976.

59. Drummond, S.E.; Ohmoto, H. Chemical evolution and mineral deposition in boiling hydrothermal systems. Econ. Geol. 1985, 80, 126-147. [CrossRef]

60. Moncada, D.; Baker, D.; Bodnar, R.J. Mineralogical, petrographic and fluid inclusion evidence for the link between boiling and epithermal Ag-Au mineralization in the La Luz area, Guanajuato Mining District, México. Ore Geol. Rev. 2017, 89, 143-170. [CrossRef]

61. Haas, J.L. The effect of salinity on the maximum thermal gradient of a hydrothermal system at hydrostatic pressure. Econ. Geol. 1971, 66, 940-946. [CrossRef]

62. Cruz-Pérez, M.A.; Canet, C.; Franco, S.I.; Camprubí, A.; González-Partida, E.; Rajabi, A. Boiling and depth calculations in active and fossil hydrothermal systems: A comparative approach based on fluid inclusion case studies from Mexico. Ore Geol. Rev. 2016, 72, 603-611. [CrossRef]

63. Bodnar, R.J.; Reynolds, T.J.; Kuhen, C.A. Fluid inclusion systematics in epithermal systems. In Geology and Geochemistry of Epithermal Systems; Berger, B.R., Bethke, P.M., Eds.; Society of Economic Geologists, INC.: Littleton, CO, USA, 1985 ; pp. 73-97.

64. Etoh, J.; Izawa, E.; Watanabe, K.; Taguchi, S.; Sekine, R. Bladed quartz and its relationship to gold mineralization in the Hishikari low-sulfidation epithermal gold. Econ. Geol. 2002, 97, 1841-1851. [CrossRef]

65. Thompson, T.B.; Trippel, A.D.; Dwelley, P.C. Mineralized veins and breccias of the Cripple Creek district, Colorado. Econ. Geol. 1985, 80, 1669-1688. [CrossRef]

66. Keith, M.; Smith, D.J.; Doyle, K.; Holwell, D.A.; Jenkin, G.R.T.; Barry, T.L.; Becker, J.; Rampe, J. Pyrite chemistry: A new window into Au-Te ore-forming processes in alkaline epithermal districts, Cripple Creek, Colorado. Geochim. Cosmochim. Acta 2020, 274, 172-191. [CrossRef]

67. Kadel-Harder, I.M.; Spry, P.G.; Layton-Matthews, D.; Voinot, A.; von der Handt, A.; McCombs, A.L. Paragenetic relationships between low- and high-grade gold mineralization in the Cripple Creek Au-Te deposit, Colorado: Trace element studies of pyrite. Ore Geol. Rev. 2020, 127, 103847. [CrossRef]

68. Karowski Łukasz Mineral-forming fluids of the Variscan Cu-porphyry formation from the Myszków-Mrzygłód area Cracovides (Silesian-Cracow region). Pr. Nauk. Uniw. Ślaskiego 1988, 929, 3-88.

69. McNaughton, N.J.; Rasmussen, B. Geochemical characterisation of xenotime formation environments using U-Th. Chem. Geol. 2018, 484, 109-119. [CrossRef]

70. Ciesielczuk, J.; Janeczek, J. metasomatic pyrite from hydrothermally altered Borów granite (Strzegom-Sobótka Massif). Preliminary report. Spec. Pap. Mineral. Soc. Pol. 2004, 24, 119-122. 
71. Sondergeld, C.H.; Turcotte, D.L. A laboratory study of mineral deposition in a boiling environment. Econ. Geol. 1979, 74, 109-115. [CrossRef]

72. Rowins, S.M. Reduced porphyry copper-gold deposits: A new variation on an old theme. Geology 2000, 28, 491-494. [CrossRef]

73. Wilkinson, J.J. Fluid Inclusions in Hydrothermal Ore Deposits. Lithos 2001, 55, 229-272. [CrossRef]

74. Lüders, V. Contribution of infrared microscopy to studies of fluid inclusions hosted in some opaque ore minerals: Possibilities, limitations, and perspectives. Miner. Depos. 2017, 52, 663-673. [CrossRef]

75. Campbell, A.R.; Robinson-Cook, S. Infrared fluid inclusion m1crothermometry on coexisting wolframite and quartz. Econ. Geol. 1987, 82, 1640-1645. [CrossRef]

76. Roedder, E. Occurrence and significance of magmatic inclusions and silicate liquid immiscibility. Acta Geol. Pol. 1984, 34, 139-178.

77. Kampmann, T.C.; Jansson, N.F.; Stephens, M.B.; Majka, J.; Lasskogen, J. Systematics of hydrothermal alteration at the falun base metal sulfide deposit and implications for ore genesis and exploration, Bergslagen Ore District, Fennoscandian Shield, Sweden. Econ. Geol. 2017, 112, 1111-1152. [CrossRef]

78. Rabbia, O.M.; Hernández, L.B.; French, D.H.; King, R.W.; Ayers, J.C. The El Teniente porphyry Cu-Mo deposit from a hydrothermal rutile perspective. Miner. Depos. 2009, 44, 849-866. [CrossRef]

79. Pal, D.C.; Chaudhuri, T.; McFarlane, C.; Mukherjee, A.; Sarangi, A.K. Mineral chemistry and in situ dating of allanite, and geochemistry of its host rocks in the Bagjata uranium mine, Singhbhum shear zone, India-implications for the chemical evolution of REE mineralization and mobilization. Econ. Geol. 2011, 106, 1155-1171. [CrossRef]

80. Hezarkhani, A.; Williams-Jones, A.E.; Gammons, C.H. Factors controlling copper solubility and chalcopyrite deposition in the Sungun porphyry copper deposit, Iran. Miner. Depos. 1999, 34, 770-783. [CrossRef]

81. Pieczka, A.; Gołębiowska, B.; Parafiniuk, J. Formation conditions of sulphide mineralization in the Rẹdziny area (West Sudetes, Poland). Spec. Pap. Mineral. Soc. Pol. 2005, 26, 229-231.

82. Xiang Ping, G.; Watanabe, M.; Ohkawa, M.; Hoshino, K.; Shibata, Y.; Desong, C. Felbertalite and related bismuth sulfosalts from the Funiushan copper skarn deposit, Nanjing, China. Can. Mineral. 2001, 39, 1641-1652. [CrossRef]

83. McClay, K.R.; Ellis, P.G. Deformation of pyrite. Econ. Geol. 1984, 79, 400-403. [CrossRef]

84. Ortelli, M.; Kouzmanov, K.; Wälle, M.; Dilles, J.H. Comparative study of fluid inclusions trapped in co-genetic ore and gangue minerals. In Proceedings of the Mineral Resources in a Sustainable World 13th SGA Biennial Meeting 2015, Nancy, France, 24-27 August 2015; pp. 505-508. 